\title{
Ankyrin Repeat and SOCS Box Protein 2
}

National Cancer Institute

\section{Source}

National Cancer Institute. Ankyrin Repeat and SOCS Box Protein 2. NCI Thesaurus. Code C132169.

Ankyrin repeat and SOCS box protein 2 (587 aa, $\sim 65 \mathrm{kDa}$ ) is encoded by the human ASB2 gene. This protein is involved in the recognition of substrates by the Elong in-Cullin-SOCSbox protein (ECS) E3 ubiquitin-protein ligase complex. 